\title{
KONTEMPLASI DAN ANALISIS TERHADAP KLASIFIKASI DAN POLITIK HUKUM PENEGAKAN HAM DI INDONESIA
}

(Contemplation and Analysis of Classification and Political Law of Human Rights Enforcement in Indonesia)

\author{
Mardenis \\ Fakultas Hukum Universitas Andalas \\ Kampus Limau Manis, Padang-25163 \\ Email: mardenis61@yahoo.co.id
}

Naskah diterima: 23 Oktober 2013; revisi: 4 November 2013; disetujui: 25 November 2013

\begin{abstract}
Abstrak
Hak Asasi Manusia saat ini menjadi salah satu isu global serta mempengaruhi hubungan internasional. Artikel ini akan membahas bagaimana klasifikasi HAM yang ideal sehingga dapat mewakili pengertian HAM yang sesuai dengan nilai-nilai falsafah Pancasila dan bagaimana politik hukum penegakan HAM di Indonesia. Dengan menggunakan penelitian yuridis normatif, disimpulkan bahwa klasifikasi HAM yang ideal adalah: hak untuk hidup, hak untuk bicara dan menyampaikan pendapat, hak untuk kebebasan berkumpul, hak untuk turut serta dalam pemerintahan, hak untuk melanjutkan keturunan, hak untuk mendapatkan kesejahteraan, hak untuk memperoleh keadilan, hak untuk beragama dan menjalankan ibadah, dan hak atas kedudukan yang sama dihadapan hukum. Politik hukum terkait HAM di Indonesia sangat ditentukan terutama oleh kepahaman dan kesadaran para elit politik dan pemerintahan yang berkuasa atas nilai-nilai luhur falsafah bangsa Indonesia yang bertumpu pada keseimbangan, keserasian dan keselarasan dalam arti yang seluas-luasnya antara hak asasi manusia, kewajiban asasi manusia, dan tanggung jawab asasi manusia
\end{abstract}

Kata kunci: HAM, klasifikasi, politik, Pancasila

\section{Abstract}

Nowadays, human rights is one of global issues and influence international relationship. This paper will explain the classification of human rights which in line with the conception and principles of Pancasila, and also expalin the political enforcement of human right in Indonesia. Byyuridis normative methode, it could be concluded that human rights classification should consist of: right to life, right to speak and expressing idea, right to organize, right to govern participation, right to breed, right to welfare, right to justice, right to religious, and right to equal before the law. The political of law related with human rights is depend on political elite and government's understanding and awareness of concept and philosophy of nation which give priority to balance and harmonize of human rights, human order, and human responsibility.

Keywords: human right, classification, politic, Pancasila 


\section{A. Pendahuluan}

Arus reformasi yang bergulir di Indonesia pada tahun 1998 yang ditandai dengan runtuhnya rezim Orde Baru yang telah berkuasa selama kurang lebih 32 tahun, telah membuka koridor bagi penegakan hukum dan hak asasi manusia (HAM).

Kondisi ini dimungkinkan dengan adanya era globalisasi yang melanda ke berbagai dunia. Salah satu ciri terjadinya globalisasi dapat dilihat dalam kondisi hubungan antar negara yang disebut sebagai borderless word atau dunia tanpa batas. Era globalisasi membawa konsekuensi adanya penghilangan sekat/batas antar negara, bahkan dengan menggunakan teknologi canggih seperti penggunaan Satelit Palapa sebagai sarana komunikasi dapat digunakan negara adidaya (AS) untuk menyadap percakapan penting yang terkait dengan situasi politik dan keamanan Indonesia. Dengan kata lain sebagai perilaku pemerintah maupun rakyat, Indonesia dapat dipantau oleh negara lain, termasuk penegakan hukum dan hak asasi manusia di Indonesia.

Di sisi lain, dengan era globalisasi juga membawa konsekuensi nilai-nilai budaya asing juga dengan deras masuk ke setiap celah kehidupan bangsa Indonesia, termasuk ke dalam kehidupan kenegaraannya. Kita tentu tidak mengatakan semua nilai-nilai budaya asing (barat) itu negative, namun sebagai bangsa yang lama di bawah jajahan bangsa barat, ada kecenderungan bangsa ini memiliki "daya saring" (filter) yang lemah berhadapan dengan nilai-nilai barat tersebut.
Meskipun hakikat dasar hak-hak asasi manusia (HAM) itu bersifat kodrati, universal dan abadi, namun pada kenyataannya di setiap negara memberi klasifikasi HAM yang berbeda-beda, tergantung pada nilai idiologi dan kondisi kekinian yang dihadapi negara yang bersangkutan. Contoh kongkrit, ketika Argentina menjadi negara demokrasi diakhir 1980-an dimunculkanlah klasifikasi-klasifikasi HAM dalam hukum positifnya (act of human rights) yang sesungguhnya telah menabrak keluhuran HAM yang kodrati, universal dan abadi, misalnya hak (kebebasan) untuk memiliki senjata api. ${ }^{1}$

Di Indonesia-pun kurang lebih demikian, sejak era reformasi, telah memasukkan hak anak dan wanita sebagai bagian dari klasifikasi HAM, ${ }^{2}$ sehingga memunculkan pertanyaan : "apakah anak dan wanita itu bukan manusia?" Anak dan wanita adalah sama dengan kaum pria (laki-laki) sebagai subjek HAM yang wajib dilindungi hakhaknya dari tindakan kedzhaliman pihak lain yang melalui kuasanya (kekuasaannya) dapat mencabut hak-hak yang dimaksud.

Kemungkinan besar dalam permusuhan klasifikasi HAM di Indonesia tersebut diatas, sangat dipengaruhi oleh isu perjuangan gender dan kondisi riil di masyarakat barat yang memang sedang dilanda krisis spiritual yang sangat parah sebagai konsekuensi logis dari budaya liberal dan hedonis.

Mengacu pada kondisi faktual diatas, maka perlu perumusan klasifikasi HAM yang representatif berdasarkan nilai-nilai dan hakekat yang terkandung dalam pengertian HAM itu

Paul A.Freund, Human Rights in Argentina (Newyork: Harper \& Publisher, 1993), hlm. 39.

Lihat Undang-Undang Nomor 39 Tahun 1999 tentang HAM, khususnya pasal 45-53. 
sendiri. Hal ini yang hendak direnungkan dalam tulisan ini.

\section{B. Permasalahan}

Berdasarkan uraian pada bagian pendahuluan di atas, maka permasalahan yang di bahas dalam tulisan ini adalah:

1. Bagaimanakah klasifikasi HAM yang ideal sehingga dapat mewakili pengertian HAM yang sesuai dengan nilai-nilai Falsafah Pancasila?

2. Bagaimana politik hukum penegakan HAM di Indonesia?

\section{Metode Penelitian}

Penelitian ini merupakan penelitian yuridis normatif. Jenis data yang digunakan adalah bahan hukum primer yang bersumber pada konvensi-konvensi HAM Internasional dan Undang-Undang HAM Nasional serta dilengkapi dengan pendapat beberapa pakar mengenai isu yang dibahas. Penelusuran data dilakukan dengan studi pustaka. Pendekatan yang digunakan adalah pendekatan terhadap Konvensi-Konvensi HAM Internasional dan Undang-Undang HAM Naasional dalam bentuk content analysis, pendekatan konsep dan pendekatan kasus. Data diolah secara deskriptif kualitatif untuk menjawab pertanyaan penelitian dengan menekankan analisis menggunakan ketiga pendekatan tersebut di atas.

\section{Pembahasan}

\section{Pengertian}

Secara terminologis, upaya perlindungan terhadap manusia terdapat banyak istilah, seperti HAM (hak asasi manusia), yang dalam bahasa Britania Raya (Inggris) disebut dengan "human rights", dalam bahasa Belanda dikenal dengan "mensenrechten" dan dalam bahasa Prancis dikenal dengan istilah"droits de l'home". Ada juga istilah "hak-hak dasar manusia" (selanjutnya disingkat HDM) yang dalam bahasa Inggris disebut "fundamental rights", dalam bahasa Belanda dikenal dengan "grondrechten", dan dalam bahasa Prancis disebut dengan "droit fundamentaux". ${ }^{3}$ Terdapat pula istilah "hak asasi" saja, tanpa mencantumkan "manusia" dibelakangnya, dengan argumentasi bahwa satu-satunya mahluk yang diciptakan Tuhan di muka bumi ini yang mempunyai hak asasi hanyalah manusia semata. ${ }^{4}$

Terdapat 2 (dua) istilah yang prinsipil dari uraian di atas, yakni: (1). Hak-Hak Asasi Manusia (HAM); (2). Hak-Hak Dasar Manusia (HDM). Kedua istilah ini memang mempunyai perbedaan-perbedaan, antara lain : Pertama, istilah HDM lebih fundamental sifatnya dari pada HAM; Kedua, istilah HDM merupakan istilah yang digunakan dalam domain hukum tata negara, sedangkan HAM merupakan istilah yang digunakan dalam hukum internasional.

Menelusuri pengertian HAM secara teoritik dapat dijumpai pada pendapat Miriam Budiardjo ${ }^{5}$ yang mengatakan bahwa: "hak azasi

Sri Soemantri Martosoewignjo, "Hukum \& Hak-Hak Dasar Manusia" (disampaikan sebagai materi kuliah pada Hari Sabtu Tanggal 2 Desember 2006).

4 Bandingkan dengan Miriam Budiardjo, Dasar-Dasar Ilmu Politik (Jakarta: Gramedia Pustaka Utama, 1991), hlm.120).

5 Ibid. 
adalah hak yang dimiliki manusia yang telah diperoleh dan dibawanya bersamaan dengan kelahirannya di dalam kehidupan masyarakat". Jelasnya bahwa hak-hak itu dimilikinya tanpa perbedaan atas dasar bangsa, ras, agama atau kelamin, oleh sebab itu bersifat asasi dan universal. Dasar dari semua hak asasi dimaksud adalah bahwa manusia harus memperoleh kesempatan untuk berkembang sesuai dengan bakat dan cita-citanya.

Pemahaman di atas berbeda dengan rumusan pengertian HAM yang terdapat dalam Pasal 1 angka (1) Undang-Undang Nomor 39 Tahun 1999, yang menegaskan bahwa:

\begin{abstract}
"Hak Asasi Manusia adalah seperangkat hak yang melekat pada hakekat keberadaan manusia sebagai mahluk Tuhan Yang Maha Esa dan merupakan anugerahnya yang wajib dihormati, dijunjung tinggi dan dilindungi oleh negara, hukum pemerintah, dan setiap orang demi kehormatan serta perlindungan harkat dan martaban manusia."
\end{abstract}

Pengertian HAM ini yang telah menjadi idiom hukum positif (ius constitutum) di Indonesia harus diberi garis bawah yang bersifat kritikal, yakni kata "seperangkat" menunjukkan "kekerdilan" muatan yang hendak dicakup oleh sebuah definisi, terutama yang bersangkut paut dengan HAM. Sebab, kata "seperangkat" berasal dari kata dasar "perangkat" yang artinya "perlengkapan",, dengan demikian ia (perangkat) hanyalah sebagai pelengkap bagi kehidupan manusia bukan sebgai inner (inti) yang melekat pada diri manusia.

Demikian juga dengan kata "anugerah Nya'. Sebenarnya kalaulah bangsa Indonesia konsisten dengan rumusan bahwa HAM adalah anugrah-
Nya, maka hal itu mengandung konsekuensi bahwa penggunaan HAM oleh bangsa Indonesia haruslah sesuai dengan keinginan (aturan) Tuhan si pemberi HAM tersebut. Maknanya adalah, ketika seseorang melakukan sesuatu perbuatan yang bertentangan dengan ajaran agama, maka yang bersangkutan tidak dapat berapologi bahwa hal tersebut merupakan bagian dari HAM-nya yang tidak seorangpun berhak/boleh melarangnya.

Karena itu, adalah tidak tepat jika pornaksi di layar televisi dan di tempat-tempat umum lainnya misalnya dikatakan pelakunya sebagai bagian dari HAM, karena aturan Tuhan (agama) melarang umatnya melakukannya.

Di samping pengertian HAM, menurut Undang-Undang Nomor 39 Tahun 1999, juga terdapat pengertian HAM dalam TAP MPR Nomor XVII/MPR/1998 tentang HAM yang menegaskan bahwa "Hak Asasi Manusia adalah hak-hak dasar yang melekat pada diri manusia secara kodrati, universal dan abadi sebagai karunia Tuhan Yang Maha Esa". Dari pengertian ini dapat diterjemahkan bahwa: Pertama, hakhak dasar itu melekat secara inner kepada diri manusia, bukan diada-adakan. Kedua, secara kodrati, artinya sifat asli yang dialami karena kekuasaan Tuhan Yang Maha Esa. Ketiga, secara universal, artinya tidak dibatasi oleh ruang. Dan Keempat, secara abadi, artinya tidak dibatasi oleh waktu dan Kelima, karunia Tuhan Yang Mahas Esa, adalah dasar dari hakikat keberadaan manusia sebagai mahluk ciptaan Tuhan Yang Maha Esa.

Menurut Sri Soemantri Martosoewignjo, pengertian HAM dalam ketetapan MPR Nomor

Tim Penyusun Kamus Pusat Pembinaan dan Pengembangan Bahasa, Kamus Besar Bahasa Indonesia (Jakarta: Depdiknas \& Balai Pustaka, 1995), hlm. 752. 
XVII/MPR/1998 di atas didasarkan pada 2 (dua) perspektif, yakni: Pertama, HAM didasarkan pada konsep hukum kodrat, yang maksudnya bahwa HAM itu ada sejak manusia dilahirkan bahkan sejak pada saat berada di alam rahim. Kedua, HAM didasarkan pada konsep ketuhanan, yang dapat dipahami bahwa manusia itu merupakan ciptaan Tuhan.

Berdasarkan uraian pengertian-pengertian terdahulu, maka dapat dirumuskan pengertian baru yang menurut hemat penulis sangat representatif sebagai pengertian HAM yang sesuai dengan nilai-nilai Falsafah Pancasila, yakni: "Hak-Asasi Manusia adalah hak-hak dasar yang melekat pada diri manusia secara kodrati, universal, abadi dan merupakan anugerah Tuhan Maha Pencipta". Pengertian ini hampir sama dengan rumusan TAP MPR Nomor XVII/ $M P R / 1998$, yang juga memasukkan frase "....sebagai anugerah Tuhan Yang Maha Esa".

Menurut penulis, frase ini sangat penting untuk memberikan penekanan agar pemahaman dan penggunaan HAM di Indonesia tidak sampai "kebablasan" sehingga menjurus kepada penggunaan paham Liberal, sekuler dan hedonistic. ${ }^{7}$

Sebagaimana diketahui bahwa dalam ajaran hukum kodrat berdasarkan pemikiran skolastik dari Thomas Aquinas, Gratianus, John Salisbury, Dante, Pierre Dubois, Marsillius Padua, John Wycliffe maupun Johannes Haus memberikan jalan berpikir bahwa hukum kodrati adalah hukum yang berlaku secara universal dan abadi yang bersumber dari Tuhan (irasional) dan yang bersumber dari akal (rasio) manusia. ${ }^{8}$ Filsafat Thomas Aquinas misalnya, mengajarkan keterkaitan erat ajarannya dengan teologia (Ilmu Ketuhanan), la mengaku bahwa di samping kebenaran wahyu juga terdapat kebenaran akal. ${ }^{9}$ Tak terkecuali Hugo de Groot alias Grotius ${ }^{10}$ memberi konklusi atas teorinya bahwa: "hukum kodrat itu diperoleh manusia dari akalnya, tetapi Tuhanlah yang memberi kekuatan mengikatnya". Jelas kiranya bahwa mengaitkan HAM dengan aspek ketuhanan sejalan dengan ajaran hukum kodrat.

\section{Sejarah Hak-Hak Asasi Manusia}

Dalam perjalanan sejarah umat manusia di permukaan bumi ini, tercatat banyak kejadian dimana seseorang diambil hak-haknya oleh orang lain tanpa memperhatikan hukum-hukum yang telah ditentukan oleh Allah SWT. Sebagai contoh adalah kasus anak-anak Adam dan Hawa, yakni Kabil yang harus membunuh Habil untuk memperebutkan gadis yang menjadi kembaran mereka masing-masing. ${ }^{11}$ Perjuangan konseptual mengenai HAM sesungguhnya dapat ditelusuri pada karya Plato $^{12}$ yang berjudul "politea", sebagai ekspresi keprihatinan yang referensial dari Plato atas keadaan negaranya yang dipimpin oleh orang yang harus akan

7 Bandingkan : Shidarta, Karakteristik penalaran Hukum dalam konteks ke Indonesiaan (Bandung: CV.Utomo, 2006), hlm. 234-235.

$8 \quad$ Lili Rasyidi \& Ira Tania Rasyidi, Pengantar Filsafat Hukum (Bandung, Bandar Maju, 2002), hlm. 53.

9 Darji Darmo Dihardjo \& Sidharta, Pokok-Pokok Filsafat Hukum, Apa dan Bagaimana Filsafat Hukum Indonesia, (Jakarta: Gramedia Pustaka Utama, 2006), hlm. 104-105.

10. Ibid., hlm. 111.

11 Abdul Majid An-Najjar, Op.Cit., hlm. 65.

12 Azhary, Negara Hukum Indonesia; Analisis Yuridis Normatif Tentang Unsur-Unsurnya, (Jakarta: UI Press, 1995), hlm. 19. 
harta, kekuasaan dan gila hormat, pemerintah sewenang-wenang di atas pemderitaan rakyatnya.

Pandangan atas perlindungan HAM oleh para pemikir berlanjut terus pada abad ke 17 dan 18, seperti yang dirumuskan oleh John Locke (1632-1714), Jean Jaques Rousseau (1712-1778), meskipun rumusan-rumusan yang dikemukakan oleh kedua pakar ini masih terbatas pada hak-hak yang bersifat politis saja, seperti kesamaan hak, hak atas kebebasan, hak untuk memilih dan sebagainya. ${ }^{13}$ Disamping kontribusi pemikiran Lock dan Rousseau ini ada juga pendapat Jeremy Bentham ${ }^{14}$ yang memasukkan hak untuk mendapatkan kesejahteraan, kebahagiaan dan rasa aman sebagai salah satu unsur HAM. Lain lagi dengan John Rawls ${ }^{15}$ yang mengatakan bahwa induk dari HAM adalah "keadilan", apabila keadilan tercapai maka dengan sendirinya akan tercapai hak-hak yang lainnya.

Ada juga segolongan manusia mengadakan perlawanan terhadap penguasa atau golongan lain untuk memperjuangkan apa yang dianggap haknya. Seiring dengan perjuangan ini, di dunia barat telah berulang kali merumuskan atau memperjuangkan beberapa hak yang dianggap suci dan harus dijamin. Dalam proses ini telah lahir beberapa naskah formal yang secara berangsur-angsur menetapkan bahwa ada beberapa hak yang mendasari kehidupan manusia karena itu bersifat universal dan abadi. $^{16}$

Secara historis, naskah dimaksud antara lain: ${ }^{17}$

(1) Magna Charta (1215), sebagai Piagam Agung 1215, yakni dokumen yang mencatat beberapa hak yang diberikan oleh Raja John dari Britania Raya (Inggris) kepada beberapa bangsawan bawahannya atas tuntutan mereka. Naskah ini sekaligus membatasi kekuasaan Raja John;

(2) Bill of Rights (1869), sebagai UndangUndang Hak 1869, yakni suatu UndangUndang yang diterima oleh parlemen Inggris sesudah berhasil dalam tahun sebelumnya mengadakan perlawanan terhadap Raja James II, dalam suatu revolusi tak berdarah yang gemilang (The Glorious Revolution of 1688);

(3) Declaration des droits d l'homme et du citoyen (1789), sebagai pernyataan hakhak asasi manusia dan warga Negara 1789, yakni suatu naskah yang dicetuskan pada permulaan revolusi Prancis sebagai perlawanan terhadap kesewenangwenangan raja dan mampu menjebol penjara Bastille di Paris.

(4) Declaration of Independent (1789), pernyataan kebebasan rakyat Amerika Serikat, yakni sebagai naskah kemerdekaan Amerika yang disusun sejak 1776 dan

Miriam Budiardjo, Op. Cit., hlm.121.

14 Jeremy Bentham, Teori Perundang-Undangan; Prinsip-Prinsip Legislasi, Hukum Perdata dan Hukum Pidana (Bandung: Nusa Media \& Nuansa, 2006), hlm. 138-140.

15. John Rawls, Teori Keadilan; Dasar-Dasar Filsafat Politik Untuk Mewujudkan Kesejahteraan Sosial Dalam Negara, (Yogyakarta: Pustaka Pelajar, 2006), hlm. 144.

16 Miriam Budiardjo, Op.Cit., hlm. 120.

17 Ibid., hlm. 120-121. 
menjadi pembukaan dari Konstitusi Amerika Serikat pada 1791.

(5) Universal Declaration of Human Rights (1948), yakni sebagai pernyataan sedunia tentang hak-hak asasi manusia oleh negara-negara yang tergabung dalam UNO (United Nation Organization), yang dalam bahasa Indonesia disingkat dengan PBB (Perserikatan Bangsa-Bangsa). Menurut Jimly Asshiddiqie, ${ }^{18}$ pernyataan (deklarasi) ini mengandung nilai-nilai universal yang wajib dihormati.

\section{Perjuangan HAM di Indonesia}

Isu tentang HAM di Indonesia, sebenarnya bukan "barang" yang baru, karena sesungguhnya masalah HAM sudah disinggung oleh para Founding Fathers Indonesia, walaupun tidak disebutkan secara eksplisit, yakni di dalam Alinea 1 Pembukaan UUD-1945, yang isinya menyatakan: "Bahwa sesungguhnya kemerdekaan itu.....dan oleh sebab itu, maka penjajahan diatas dunia harus dihapuskan karena tidak sesuai dengan prikemanusiaan dan prikeadilan". Dengan adanya penghargaan terhadap HAM, bangsa Indonesia yang merdeka pada tanggal 17 Agustus 1945 dapat disebut sebagai negara yang berdasarkan hukum. Rasionya bahwa dalam negara hukum harus ada elemen-elemen sebagai berikut: (1) Asas pengakuan dan perlindungan terhadap HAM; (2) asas legalitas; (3) asas pembagian kekuasaan; (4) asas peradilan yang bebas dan tidak memihak; dan (5) asas kedaulatan rakyat. ${ }^{19}$

Akan tetapi penghargaan terhadap HAM yang sudah dirancangkan oleh para founding fathers di Indonesia tidak berjalan sebagaimana mestinya, seiring dengan perjalanan panjang bangsa Indonesia dalam 3 (tiga) Orde, yakni: ${ }^{20}$

(1) Penegakan HAM pada Orde Lama:

Orde Lama merupakan kelanjutan pemerintahan pasca kemerdekaan 17 Agustus 1945 yang lebih menitik beratkan pada perjuangan revolusi, sehingga banyak peraturan perundang-undangan yang dibuat atas nama revolusi yang telah dikooptasi oleh kekuasaan eksekutif, seperti Undang-Undang Nomor 19 Tahun 1964 tentang Ketentuan-Ketentuan Pokok Kekuasaan Kehakiman, yang memungkinkan campur tangan presiden terhadap kekuasaan kehakiman dan Penetapan Presiden Nomor 11 /PNPS/1963 tentang Pemberantasan Kegiatan Subversi yang tidak sesuai (bertentangan) dengan HAM.

(2) Penegakkan HAM pada Orde Baru:

Orde Baru yang berdiri sebagai respon terhadap gagalnya Orde Lama telah membuat perubahan-perubahan secara tegas dengan membangun demokratisasi dan perlindungan HAM melalui Pemilu Tahun 1971. ${ }^{21}$ Namun, setelah lebih dari satu dasawarsa, nuansa demokratisasi dan perlindungan HAM yang dijalankan Orde Baru mulai bias, yang ditandai dengan maraknya praktek KKN (Korupsi,

18 Jimly Asshiddiqie, Konstitusi dan Konstitusionalisme Indonesia (Jakarta: Sekretariat Jenderal dan Kepaniteraan Mahkamah Konstitusi RI, 2006).

19 Lili Rasyidi dan B. Arief Sidharta, Filsafat Hukum Mazhab dan Refleksinya, (Bandung: Remaja Karia, 1989), hlm. 185.

20 Muladi, Demokratisasi, Hak Asasi Manusia dan Reformasi Hukum di Indonesia (Jakarta: The Habibie Centre, 2002), hlm. 49.

21 Muladi, Op.Cit., hlm. 50. 
Kolusi,dan Nepotisme) serta berbagai rekayasa untuk kepentingan politik dan penguasa. Seringkali, pemerintah di masa Orde Baru melakukan tindakan-tindakan yang dapat di kategorikan sebagai crimes by government atau top hat crimes, seperti penculikan terhadap para aktifis pro demokrasi (penghilangan orang secara paksa) yang bertentangan dengan HAM, sekali pun tahun 1993 pemerintah sudah mendirikan Komisi Nasional Hak Asasi Manusia (KOMNAS HAM). Sebagai puncaknya, pada tahun 1998, Orde Baru jatuh dengan adanya multikrisis di Indonesia serta tuntutan adanya reformasi di segala bidang kehidupan bangsa dan negara.

(3) Penegakan HAM pada Orde Reformasi:

Orde Reformasi yang dimulai pada tahun 1998 berusaha menegakkan HAM dengan jalan membuat peraturan perundang-undangan yang terkait dengan HAM sebagai rambu-rambu, seperti Undang-Undang Nomor 39 Tahun 1999 tentang HAM, dan Undang-Undang Nomor 26 Tahun 2000 tentang Pengadilan HAM. Ratifikasi terhadap instrumen internasional tentang HAM dan UU tentang Peradilan HAM memungkinkan di bukanya kembali kasus-kasus pelanggaran HAM berat di masa lalu dan pemberantasan praktek KKN

\section{Tebaran Pikiran dan Kontemplasi Terhadap Klasifikasi HAM}

\section{(1) Tebaran Pikiran Tentang Klasifikasi HAM}

Cetusan Franklin Delano Roosevalts ${ }^{22}$ (mantan Presiden Amerika Serikat) yang sangat monumental bila dilihat dari sisi konsep klasifikasi hak-hak asasi manusia (human rights), dikenal dengan The Four Freedoms (Empat Kebebasan), yaitu: Pertama, Kebebasan untuk berbicara dan menyatakan pendapat (freedom of speech and expression); Kedua, Kebebasan beragama (freedom of religion); Ketiga, Kebebasan dari ketakutan (freedom of fear); Keempat, Kebebasan dari kemelaratan (freedom from want).

Selanjutnya Miriam Budiardjo ${ }^{23}$ berpendapat bahwa klasifikasi HAM dapat dibedakan atas 7 (tujuh) hak, yakni: (1) Hak atas kebebasan mengeluarkan pendapat; (2) Hak atas kedudukan yang sama di dalam hukum; (3) Hak atas kebebasan berkumpul; (4) Hak atas kebebasan beragama; (5). Hak atas penghidupan yang layak; (6) Hak atas kebebasan berserikat; dan (7). Hak atas pengajaran.

Menurut Sri Soemantri Martosoewignjo, ${ }^{24}$ "Human Rights Classification" (klasifikasi hak-hak asasi manusia) terdiri atas: Pertama, Respect for the integrity or the person (penghormatan terhadap ketulusan seseorang), and this includes the following freedoms, yakni : (a) freedom from political and other extrajudicial killing; (kebebasan dari politik dan tindakan ekstrajudisial orang lain), (b) Freedom from disappearance (kebebasan dari penghilangan); (c) Freedom from torture and other cruel, in human, or degrading treatment or punishment; (d) Freedom from arrest, detention or exile; (e) Freedom from denial of fair public trial. Kedua, Respect for civil liberties (penghormatan terhadap kemerdekaan sipil), yang bagiannya adalah: (a) Freedom of speech and press (kebebasan bicara dan pers); (b)

\footnotetext{
Miriam Budiardjo, Op.Cit., hlm. 121.

Ibid., hlm. 129-136.

24 Sri Soemantri Martosoewignjo, Materi Kuliah Hukum \& Hak-Hak Dasar Manusia, Sabtu, 11 November 2006.
} 
Freedom of peaceful assembly and association (kebebasan atas pertemuan damai dan berkumpul); (c) Freedom of religion (kebebasan menganut agama); (d) Freedom of movement within the country, foreign travel, emigration, and repatriation (Kebebasan meninggalkan kampung halaman, bepergian ke luar negeri, emigrasi dan pemulangan kembali). Ketiga, Respect for political rights (penghormatan terhadap hak-hak politik); the right of citizens to change their government (hak masyarakat atas perubahan rezim pemerintahan). Keempat, Government attitude regarding international and non government investigation of alleged violations of human rights. (sikap pemerintah berkenaan dengan investigasi internasional dan non pemerintah terhadap pelanggaran HAM) Kelima, Discrimination based on race, sex, religion or social status (diskriminasi atas dasar ras, kelamin, agama atau status sosial) Keenam, Worker rights (Hak-Hak pekerja/buruh), yang terdiri atas: (a) The rights of association (hak untuk berkumpul); (b) The rights to organize and bargain collectively (hak mengatur persetujuan bersama); (c) Prohibition for forced and compulsory labour (larangan untuk pemaksaan dan mewajibkan buruh); (d) Minimum age of employment of children (memperkerjakan anakanak di bawah umur); (e) Acceptable conditions of work (Kepantasan kondisi tempat bekerja).

Selanjutnya dalam Undang-Undang Nomor 39 Tahun 1999, mengklasifikasi HAM atas: (1) Hak untuk hidup; (2) Hak berkeluarga dan melanjutkan keturunan; (3) Hak mengembangkan diri; (4) Hak memperoleh keadilan; (5) Hak atas kebebasan pribadi; (6) Hak atas rasa aman; (7) Hak atas kesejahteraan; (8) Hak turut serta dalam pemerintahan; (9) Hak wanita; (10) Hak anak. Dari sepuluh klasifikasi HAM yang terkandung dalam undang-undang ini dapat memunculkan spontanitas pertanyaan: apakah wanita dan anak bukan manusia?

\section{(2) Kontemplasi Terhadap Klasifikasi HAM}

Kontemplasi ${ }^{25}$ dalam tulisan ini dapat dimaknai sebagai perenungan yang mendalam melalui prosedur ilmiah hukum. Hasil kontemplasi penulis yang mendasarkan pada pengertian HAM dan telah dirumuskan sebelumnya, ${ }^{26}$ adalah: (1) Hak untuk hidup; (2) Hak untuk bicara \& menyampaikan pendapat; (3) Hak untuk kebebasan berkumpul; (4) Hak untuk turut serta dalam pemerintahan; (5) Hak untuk melanjutkan keturunan; (6) Hak untuk mendapatkan kesejahteraan; (7) Hak untuk memperoleh keadilan; (8) Hak untuk beragama dan menjalankan ibadah; dan (9) Hak atas kedudukan yang sama di hadapan hukum.

\section{a. Hak Untuk Hidup}

Hak hidup (freedom of life) ini termasuk hak yang sangat kodrati, universal dan abadi, bahkan hak ini melekat sejak masih dalam rahim (janin dalam kandungan) hingga tinggal tulang berulang dalam kubur. Hak untuk hidup ini sangat terkait dengan hak-hak kodrati (natural rights), ${ }^{27}$ kalau tidak ada jaminan hidup bagi manusia, maka jelas manusia akan punah, dan

Tim Penyusun Kamus Pusat Pembinaan dan Pengembangan Bahasa, Op.Cit., hlm. 522.

HAM adalah hak-hak dasar yang melekat pada diri manusia secara kodrati, universal dan abadi.

27 Philipus M.hadjon, Perlindungan Hukum Bagi Rakyat Di Indonesia; Sebuah Studi Tentang Prinsip-Prinsipnya, Penanganannya Oleh Pengadilan Dalam Lingkungan Peradilan Umum dan Pembentukan Peradilan Administrasi Negara (Surabaya: Bina Ilmu, 1987), hlm. 54. 
kalau manusia itu punah tidak ada lagi khalifah di muka bumi (chalifatan fil ardhi).

\section{b. Hak Untuk Bicara dan Menyampaikan Pendapat}

Hak untuk bicara dan menyampaikan pendapat sangat berkorelasi dengan kebebasan untuk berbicara dan menyatakan pendapat (freedom of speech). Dalam Universal Declaration of Human Rights (Pasal 19) disebutkan bahwa:

\begin{abstract}
"Setiap orang berhak atas kebebasan mempunyai dan mengeluarkan pendapat; dalam hak ini termasuk kebebasan mempunyai pendapat-pendapat dengan tidak mendapat gangguan, dan untuk mencari, menerima dan menyampaikan keterangan-keterangan dan pendapatpendapat dengan cara apapun juga dan tidak memandang batas-batas".
\end{abstract}

Jelas kiranya bahwa jaminan untuk bicara dan menyampaikan pendapat secara universal termaktub dalam deklarasi universal HAM.

Di dalam Pasal 28 UUD 1945, juga terdâpat jaminan untuk bicara, yang menegaskan bahwa: "kemerdekaan berserikat dan berkumpul mengeluarkan pikiran dengan lisan dan tulisan dan sebagainya ditetapkan dengan undangundang."

\section{c. Hak Untuk Kebebasan Berkumpul}

C.F.Strong mengingatkan bahwa negara harus memperhatikan dan menjamin kepentingan perkumpulan rakyat, melalui norma-norma dalam konstitusi, paham ini yang disebut konstitusionalisme modern. ${ }^{28}$ Secara kodrati pada hakekatnya manusia itu adalah makhluk yang berkumpul atau bermasyarakat (zoon politicon), justeru itu perlu ada jaminan atas hak untuk berkumpul bagi individu. Hak ini juga bersifat unversal sebagaimana telah diatur dalam Universal Declaration of Human Rights, Pasal 20:

"(1) Setiap orang mempunyai hak atas kebebasan berkumpul dan berapat;

(2) Tiada seorang juga pun dapat melarang orang lain memasuki salah satu perkumpulan."

\section{d. Hak Untuk Turut Serta dalam Pemerintahan}

Hak untuk turut serta dalam pemerintahan ini telah diintrodusir oleh John Lock dan Rousseau, yang mereka sebut sebagai hak-hak politik dan dicontohkan seperti kesamaan hak, hak atas kebebasan, hak untuk memilih dan sebagainya ${ }^{29}$.

\section{e. Hak Untuk Melanjutkan Keturunan}

Meskipun hak ini terkait dengan menghindari kepunahan manusia, seperti halnya "hak untuk hidup" (rights of life). Akan tetapi mempunyai perbedaan dari segi kualifikasi hak dasar (fundamental rights). Kalau hak untuk hidup merupakan bagian dari hakhak dasar manusia sebagai mahluk individu (individual rights), dalam hukum perdata juga memberi perlindungan terhadap hak ini, yakni pada saat manusia sudah dewasa berhak melakukan aktivitas atas tanggungjawab sendiri, seperti misalnya hak untuk kawin, hak untuk berpoligami dan sebagai. Jelasnya hak ini terkait dengan kenikmatan sex dan kesinambungan

8 C.F.Strong, Konstitusi-Konstitusi Politik Modern; Kajian Tentang Sejarah \& Bentuk-Bentuk Konstitusi Dunia (Bandung: Nuansa \& Nusa Media, 2004), hlm. 506.

29 Miriam Budiardjo, Op.Cit., hlm. 121. 
keturunan. Oleh sebab itu, pelanggaran terhadap hak ini dapat dikategorikan sebagai pelanggaran hak asasi manusia (gross violation of human rights). ${ }^{30}$

\section{f. Hak Untuk Mendapatkan Kesejahteraan}

Hak untuk mendapatkan kesejahteraan merupakan a contrario dari kebebasan dari kemelaratan (freedom of want), artinya apabila hak untuk mendapatkan kesejahteraan tidak dijamin, maka implikasi yang muncul adalah kemelaratan. Mashab Utilitarian yang dimotori Jeremy Bentham ${ }^{31}$ telah menjadikan patokan kesejahteraan sebagai tujuan hukum, sehingga memasukkan hak untuk mendapatkan kesejahteraan dan kebahagiaan sebagai salah satu unsur HAM.

\section{g. Hak Untuk Memperoleh keadilan dan Rasa Aman}

Selain Bentham, yang telah mengintrodusir "rasa aman" sebagai acuan utama pencapaian kebahagiaan hidup, juga (rasa aman) merupakan bagian integral dari kebebasan dari ketakutan (freedom of fear). Demikian pula dengan hak untuk memperoleh keadilan, menurut John Rawls, ${ }^{32}$ induk dari HAM adalah "Keadilan", apabila keadilan tercapai maka dengan sendirinya akan tercapai hak-hak yang lainnya. Perkara keadilan semakin fundamental bila diharapkan dengan tindakan represif penguasapenguasa otoriter dan kesewenang-wenangan pengadilan.

\section{h. Hak Untuk Beragama \& Menjalankan Ibadah}

Hak ini merupakan hak yang kodrati, universal dan abadi karena hak untuk beragama tidak dapat dipisahkan dari kehidupan manusia di muka bumi. Dalam tataran filsafat moral dikatakan bahwa yang membangun moral pertama umat manusia adalah agama. ${ }^{33}$ Oleh sebab itu, hak untuk beragama dan menjalankan ibadah merupakan bagian dari kebebasan beragama (freedom of religion). Dalam pasal 29 UUD 1945 telah ditegaskan bahwa: "Negara menjamin kemerdekaan tiap-tiap penduduk untuk memeluk agamanya masing-masing dan untuk beribadat menurut agamanya dan kepercayaannya itu". Sejalan dengan Pasal 18 Declaration of Human Rights, yang menegaskan bahwa :

"Setiap orang berhak atas kebebasan pikiran, keinsyafan bathin, dan agama; dalam hal ini kebebasan berganti agama atau kepercayaan dan kebebasan untuk menyatakan agama atau kepercayaannya dengan cara mengajarkannya, melakukannya, beribadat dan menepatinya, baik sendiri maupun bersama-sama dengan orang lain dan baik ditempat umum maupun yang tersendiri."

Kendatipun demikian, dalam hal hak (kebebasan) beragama ini sudah barang tentu harus ada batasan (koridor) yang tegas bahwa kebebasan beragama yang dimaksudkan adalah kebebasan beragama dalam arti positif. Artinya bangsa Indonesia diberikan kebebasan untuk memilih agama yang diyakininya benar, tentu setelah yang bersangkutan memilih (memeluk)

\footnotetext{
30 Bandingkan dengan Muladi (Ed.), Hak Asasi Manusia; Hakekat, Konsep dan Implikasinya Dalam Perspektif Hukum dan Masyarakat (Bandung: Refika Aditama, 2005), hlm. 160.

31 Jeremy Bentham, Op.Cit. hlm. 138-140.

32 John Rawls, Op.Cit., hlm. 144.

33 Fuans Magnis Suseno, Etika Dasar; Masalah-Masalah Pokok Filsafat Moral (Yogyakarta: Kanisius, 1987), hlm. 110-111.
} 
agama tertentu, konsekuensi logisnya adalah berkewajiban menjalankan ajaran agama yang dipilihnya itu dengan baik dan konsisten. Sejalan dengan ini, maka sesuai dengan sila pertama Pancasila, maka tidak ada tempat di Indonesia bagi orang yang tidak beragama (ateis) dan tidak diperbolehkan propaganda anti agama di negeri ini.

\section{i. Hak Atas Kedudukan Yang Sama Di Hadapan Hukum}

Hak ini dapat dikatakan sangat fundamental, karena merupakan elemen penting dalam The Rule of Law, yaitu equality before the law. Sebagaimana pendapat Albert Venn Dicey ${ }^{34}$ yang mengemukakan 3 (tiga) unsur utama rule of law, yakni: (a) supremacy of law; (b) equality before the law; dan (c) constitution based on individual rights.

\section{Kontemplasi Terhadap Politik Hukum Penegakan HAM}

\section{(1) Permasalahan Penegakan HAM di Indonesia}

Sebagaimana telah dikemukakan sebelumnya, meskipun Indonesia menganut prinsip negara hukum dan demokrasi serta memiliki konstitusi yang menyatakan pemihakan pada perlindungan HAM, ternyata masih terjadi pelanggaran HAM yang sebagian besar diantaranya dilakukan oleh aparat secara masif (crimes by government).

Pada saat ini, bangsa Indonesia masih berada dalam pergulatan yang serius untuk mencari penyelesaian kasus-kasus pelanggaran HAM di masa lalu, terutama yang sifatnya masif dan dilakukan oleh aparat yang dalam banyak kasus merupakan pelanggaran HAM berat.

Tidak mudah bagi bangsa Indonesia untuk menyelesaikan pelanggaran HAM yang terjadi di masa lalu. Hasil temuan dan rekomendasi KPP HAM yang dibentuk oleh KOMNAS HAM, baik untuk kasus pelanggaran HAM pasca jajak pendapat di Timor-Timur tahun 1999 maupun untuk kasus pelanggaran HAM yang terkait dengan peristiwa Tanjung Priok tahun 1984, telah menimbulkan pro kontra yang belum memberikan arah penyelesaian yang jelas dan menyeluruh.

Sebenarnya masalah pelanggaran HAM di Indonesia bukan hanya terjadi dalam kasuskasus politik seperti kasus Timor-Timur, Aceh, Lampung, Tanjung Priok, Maluku, kasus pembunuhan Munir, dan sebagainya, melainkan terjadi juga dalam penanganan masalah-masalah kriminal yang biasa, misalnya penangkapan dan penahanan tersangka tanpa surat perintah tertulis dari pejabat yang diberi wewenang oleh undang-undang. Begitu juga pelanggaran HAM (terselubung) dalam hal-hal pelayanan publik, misalnya dibanyak rumah sakit di Indonesia setiap calon pasien yang ingin mendapatkan fasilitas perawatan (kendatipun yang bersangkutan dalam keadaan sekarat/ koma) oleh pihak manajemen rumah sakit, pihak keluarganya diharuskan menyerahkan deposit uang dalam jumlah tertentu yang sering tidak terjangkau oleh kemampuan ekonomi keluarga pasien. Tanpa itu, pihak rumah sakit tidak akan mau melayani calon pasien, kendatipun saat itu yang bersangkutan sangat membutuhkan perawatan medis secepatnya. Ini hanya salah

Dicey, dalam Azhary, Op.Cit., hlm. 39. 
satu contoh lain pelanggaran HAM yang sudah "jamak" di negeri ini.

\section{(2) Kontemplasi Politik Hukum Penegakan HAM di Indonesia}

Hak Asasi Manusia (HAM), tak pelak merupakan ide dan isu yang sangat populer saat ini. Ide inipun kemudian menjadi standar manusia untuk menilai baik dan buruk. Sesuatu yang melanggar HAM dianggap buruk; yang sesuai dengan HAM dianggap baik. HAM seakan telah menjadi "agama baru" yang menjadi pedoman hidup manusia. Tidak mengherankan kalau tidak sedikit umat Islam yang lebih rela menolak syari'at Islam atau memaksakan perubahan hukum syari'at demi mengagungkan ide HAM.

Sebagai sebuah pemikiran, HAM bertolak dari dua konsepsi yang saling terkait dan menjadi dasar bangunan ideologi kapitalisme, yakni teori hukum alam dan Liberalisme. Teori hukum alam berbicara tentang prinsip bahwa segala sesuatu ada karena begitu adanya. ${ }^{35}$ Tema sentral dalam teori ini adalah hak alamiah yang diberikan kepada setiap manusia oleh Tuhan. Teori ini awalnya dilontarkan oleh Aristoteles, lalu dikembangkan oleh Thomas Aquinas dalam konteks Eropa-Kristen. Kemudian dikembangkan lagi oleh pemikir teori kontrak sosial, yaitu Hobbes, Locke, dan Roousseau yang juga pemikir paham liberal.

Sebagai sebuah pandangan filsafat dan tradisi politik, liberalisme menjadikan kebebasan sebagai nilai politik yang paling utama. Perpaduan pemikiran teori hukum alam dan liberalisme melahirkan kredo bahwa manusia pada dasarnya baik. Adapun kejahatan yang dilakukan manusia terjadi karena adanya pengekangan terhadap manusia. Karena itu agar manusia bisa memperlihatkan sifat aslinya yang baik, manusia harus diberi kebebasan.

Kemudian secara substantif, HAM pada dasarnya memiliki 4 (empat) konsep dasar kebebasan, yaitu: kebebasan berkeyakinan, kebebasan berpendapat, kebebasan berperilaku, dan kebebasan kepemilikan. Semua ide ini, jika diterapkan tanpa bimbingan wahyu (agama) sangat berbahaya dan berdampak buruk bagi umat manusia secara keseluruhan.

Berdasarkan kebebasan berkeyakinan, manusia berhak meyakini ideologi atau agama apapun, juga mengingkari agama atau ide apapun. Hal ini jelas dapat menihilkan agama, mendangkalkan aqidah umat, menjamurkan pemurtadan serta memberi peluang propaganda anti agama.

Berdasarkan kebebasan berpendapat, setiap orang berhak menyatakan pendapat apapun, dalam hal apapun, tanpa terikat dengan batasan apapun. Manusia boleh terang-terangan bersikap kufur atau mempropagandakan ide apa saja walaupun bertentangan dengan keyakinan agama samawi. Bahkan orang boleh saja memperolok-olok ajaran agama atau Nabi agama tertentu.

Berdasarkan kebebasan berperilaku, setiap orang berhak menjalani kehidupan sesuai dengan kehendaknya selama tidak melanggar kehidupan pribadi orang lain. Seorang pria berhak menggauli wanita manapun selama wanita itu rela. Seorang berhak melakukan penyimpangan seksual selama tidak melibatkan

35 Lihat Lili Rasyidi \& Ira Thania Rasyidi, Op.Cit., hlm. 181 
anak di bawah umur. Seorang berhak makan dan minum apa saja dan berpakaian seenaknya dalam batas-batas peraturan umum. Disini tidak ada tempat bagi hukum halal-haram.

Kemudian dengan kebebasan berkepemilikan, manusia berhak memiliki segala sesuatu sesuka hatinya dan menggunakan segala sesuatu miliknya selama tidak melanggar hak orang lain.

Akibatnya, terjadi akumulasi kekayaan yang melimpah ruah di tangan segelintir orang. Dengan kelebihan kekayaannya itu, mereka berubah menjadi suatu kekuatan hegemonik yang menguasai dan mengendalikan masyarakat dan negara, baik dalam urusan politik dalam negeri maupun luar negerinya.

Berdasarkan uraian di atas pertanyaan yang ingin penulis ajukan (kembali) dalam tulisan ini adalah: Mau kemanakah politik hukum HAM Indonesia? Jawabannya akan sangat terpulang dan tentu sangat ditentukan terutama oleh kepahaman dan kesadaran para elit politik dan pemerintahan yang berkuasa saat ini akan nilai-nilai luhur falsafah bangsa Indonesia yang bertumpu pada keseimbangan, keserasian dan keselarasan dalam arti yang seluasluasnya, dalam konteks ini ialah keseimbangan, keserasian dan keselarasan antara hak asasi manusia (HAM), kewajiban asasi manusia (KAM), dan tanggung jawab asasi manusia (TAM).

Dikaitkan dengan perkembangan konsep HAM kontemporer yang tidak hanya bertumpu pada hak-hak sipil dan politik (sipol) tetapi juga meliputi hak-hak ekonomi dan sosial budaya (ekosob), maka penulis sangat setuju dengan wacana agar pelaku korupsi ke depan tidak hanya dijerat dengan Undang-Undang Anti Korupsi saja, tetapi secara kumulatif juga dapat dijerat dengan Undang-Undang HAM dan (jika perlu) juga dengan Undang-Undang Pemberantasan Terorisme. Kenapa demikian? Bukankah para koruptor tersebut dengan "syahwat" keserakahannya juga telah melanggar hak-hak rakyat miskin untuk mendapatkan kehidupan yang lebih layak dan lebih sejahtera dan bukankah mereka juga merupakan bagian dari teroris di bidang ekonomi yang telah menghancurkan sendi-sendi perekonomian nasional Indonesia. Pelanggaran terhadap hak-hak rakyat miskin untuk mendapatkan kehidupan yang lebih layak, bagaimanapun juga jelas merupakan pelanggaran terhadap HAM yang dilindungi oleh International Covenant on Economic, Social and Cultural Rights (ICESCR).

\section{E. Penutup}

\section{Kesimpulan}

Sebagai bagian akhir dari tulisan ini penulis ingin menegaskan kembali_bahwa klasifikasi HAM yang ideal sehingga dapat mewakili pengertian HAM sebagai konsep yang kodrati, universal dan abadi adalah: (1). hak untuk hidup; (2), Hak untuk bicara \& menyampaikan pendapat; (3). Hak untuk kebebasan berkumpul; (4). Hak untuk turut serta dalam pemerintahan; (5), Hak untuk melanjutkan keturunan; (6). Hak untuk mendapatkan kesejahteraan; (7). Hak untuk memperoleh keadilan; (8). Hak untuk beragama dan menjalankan ibadah; dan (9), Hak atas kedudukan yang sama dihadapan hukum.

Politik hukum terkait HAM di Indonesia sangat ditentukan terutama oleh kepahaman dan kesadaran para elit politik dan pemerintahan yang berkuasa atas nilai-nilai luhur falsafah bangsa Indonesia yang bertumpu pada keseimbangan, keserasian dan keselarasan dalam arti yang seluas-luasnya antara hak asasi manusia, kewajiban asasi manusia, dan tanggung jawab asasi manusia. 


\section{Rekomendasi}

Perlu dilakukan perubahan klasifikasi HAM dalam Undang-Undang Nomor 39 Tahun 1999, seperti yang dimaksud dalam klasifikasi HAM hasil kesimpulan tulisan ini.

Agar penerapan HAM tidak membawa kepada kerusakan dan kehancuran terhadap kehidupan umat manusia, maka perlu ada ketegasan dan kesepakatan bahwa klasifikasi dan penerapan HAM harus disesuaikan dan tidak boleh bertentangan dengan nilai-nilai agama dan nilai falsafah bangsa sebagai bagian nilai HAM partikular yang diakui dan dilindungi oleh Konvensi-konvensi HAM Internasional, terutama dalam Deklarasi HAM Kairo (1990) dan Deklarasi HAM Wina (1993).

\section{DAFTAR PUSTAKA}

\section{Buku:}

Asshidiqie, Jimly, Konstitusi dan Konstitusionalisme Indonesia (Jakarta: Sekretariat Jenderal dan Kepaniteraan Mahkamah Konstitusi RI, 2006).

A. Freund, Paul, Human Rights in Argentina (New York: Harper \& Row Publishers, 1993).

Atmasasmita, Romli, Reformasi Hukum, Hak Asasi Manusia \& Penegakkan Hukum (Bandung: CV. Mandar Maju, 2001).

Azhary, Negara Hukum Indonesia; Analisis Yuridis Normatif Tentang Unsur-Unsurnya (Jakarta: UI Press, 1995).

Bentham, Jeremy, Teori Perundang-Undangan; Prinsip-Prinsip Legislasi, Hukum Perdata dan Hukum Pidana (Bandung: Nusa Media \& Nuansa, 2006).

Budiardjo, Miriam Dasar-Dasar Ilmu Politik (Jakarta: Gramedia Pustaka Utama, 1991).

Darmodihardjo, Darji \& Sidharta, Pokok-Pokok Filsafat Hukum; Aparat dan Bagaimana Filsafat Hukum Indonesia (Jakarta: Gramedia Pustaka Utama, 2006).

El-Muhtaj, Majda, Hak Asasi Manusia dalam Konstitusi Indonesia (Jakarta: Prenada Media, 2005).

Mahfud, Moh, M.D., Membangun Politik Hukum; Menegakkan Konstitusi (Jakarta: LP3ES, 2006).
Majid, Abdul An-najjar, Kebebasan Berfikir Dalam Islam; Upaya Mempersatukan Visi Pemikiran Dalam Islam (Jakarta: Pustaka Firdaus, 2002).

Matindas, Beni E, Negarakertagama; Kimia Kerukunan (Jakarta: Bina Insani, 2001).

Muladi (Ed.), Hak Asasi Manusia; Hakekat, Konsep dan Implikasinya Dalam Perspektif Hukum dan Masyarakat (Bandung: Refika Aditama, 2005).

M. Hadjon,Philipus, Perlindungan Hukum Bagi Rakyat di Indonesia; Sebuah Studi Tentang Prinsip-Prinsipnya, Penanganannya Oleh Pengadilan Dalam Lingkungan Peradilan Umum dan Pembentukan Peradilan Administrasi Negara (Surabaya: Bina llmu, 1987).

Rasjidi, lili \& Thania, Ira Rasjidi, Pengantar Filsafat Hukum (Bandung: Mandar Maju, 2002).

Rawls, John, Teori Keadilan; Dasar-Dasar Filsafat Politik Untuk Mewujudkan Kesejahteraan Sosial Dalam Negara (Yogyakarta: Pustaka Pelajar, 2006).

Shidarta, Karakteristik Penalaran Hukum Dalam Konteks Keindonesiaan (Bandung: CV. Utomo, 2006).

Strong, C.F., Konstitusi Politik Modern; Kajian Tentang Sejarah \& Bentuk-Bentuk Konstitusi Dunia (Bandung: Nuansa \& Nusa Media, 2004).

Suseno, Frans Magnis, Etika Dasar; MasalahMasalah Pokok Filsafat Moral (Yogyakarta: Kanisius, 1987).

Tim Penyusun Kamus Pusat Pembinaan dan Pengembangan Bahasa, Kamus Besar Bahasa Indonesia (Jakarta: Departemen Pendidikan dan Kebudayaan \& Balai Pustaka, 1995).

\section{Makalah / Artikel / Prosiding / Hasil Penelitian}

Martosoewignjo, Soemantri Sri, "Materi Kuliah Hukum \& Hak-Hak Dasar Manusia", Sabtu, 2 Desember 2006.

Martosoewignjo, Soemantri Sri, "Materi Kuliah Hukum \& Hak-Hak Dasar Manusia", Sabtu, 11 November 2006.

\section{Peraturan}

Undang-Undang Dasar Negara Republik Indonesia Tahun 1945

Ketetapan MPR No. XVII/ MPR/ 1998 tentang HAM Undang-Undang Nomor 39 Tahun 1999 tentang Hak Asasi Manusia.

Universal Declaration of Human Rights 1948

Cairo Declaration of Islamic Human Rights 1990

Wina Declaration of Human Rights 1993 